\title{
FORMULASI DAN AKTIVITAS ANTIOKSIDAN PERMEN JELLY SARI BUAH PEPAYA CALIFORNIA (Carica papaya L.)
}

\author{
Mira Miranti, Bina Lohitasari, Desy Rizky Amalia Program \\ Studi Farmasi, FMIPA, Universitas Pakuan Bogor Email: \\ mira.miranti@unpak.ac.id
}

\begin{abstract}
ABSTRAK
Permen Jelly merupakan permen yang terbuat dari campuran sari buah-buahan, bahan pembentuk gel dengan penambahan essens untuk menghasilkan berbagai macam rasa, dengan bentuk fisik jernih transparan serta mempunyai tekstur yang kenyal. Penelitian ini bertujuan untuk menentukan kadar vitamin $\mathrm{C}$ sari buah dan permen jelly sari buah pepaya California (Carica papaya L.), menentukan nilai IC50 sari buah dan permen jelly sari buah pepaya California (Carica papaya L.), serta menentukan stabilitas permen jelly sari buah pepaya California (Carica papaya L.). Pada penelitian ini, dibuat permen jelly dibuat 4 formula yaitu formula 0,$1 ; 2$, dan 3 dengan variasi konsentrasi sari pepaya yaitu 0\%, 20\%, 25\%, dan 30\%.

Hasil uji kadar vitamin $C$ pada sari buah pepaya California yaitu 0,0467\%. Hasil uji aktivitas antioksidan dengan menggunakan DPPH (1,1-difenil-2-pikrihidrazil) sari buah pepaya California memiliki IC50 sebesar 33,537 ppm dan pada permen jelly formula 1, 2, dan 3 yaitu sebesar 75,296 ppm, 73,901 ppm, dan 70,698 ppm. Uji stabilitas dilakukan selama 4 minggu penyimpanan pada suhu ruangan. Hasil pengujian aktivitas antioksidan pada minggu ke 1 sampai ke 4 didapat nilai IC50 berturut-turut yaitu formula 1 sebesar $81,171 \mathrm{ppm}, 89,573 \mathrm{ppm}, 97,178 \mathrm{ppm}$, dan 102.126 ppm, formula 2 sebesar 79,175 ppm, 88,158 ppm, 96,441 ppm, dan 100,378 ppm, sedangkan pada formula 3 sebesar 77,255 ppm, 85,482 ppm, 93,680 ppm,dan 100,267 ppm. Secara organoleptik permen jelly memiliki rasa, warna, aroma serta kekenyalan mengalami perubahan yang signifikan.
\end{abstract}

Kata Kunci : Permen jelly, Buah Pepaya California (Carica papaya L), Antioksidan

\begin{abstract}
Jelly is a candy made from a mixture of fruit juice, gelling material with the addition of essens to produce a wide variety of flavors, with clear transparent physical form and has a chewy texture. This study aims to determine the vitamin $\mathrm{C}$ content of fruit juice and fruit juice jelly candies California papaya (Carica papaya L.), determine the $\mathrm{IC}_{50}$ value fruit juice and fruit juice jelly candies California papaya (Carica papaya L.), and to determine the stability of the jelly juice California papaya (Carica papaya L.). In this study, made jelly made 4 formula is formula 0,$1 ; 2$, and 3 with a variation of papaya juice concentrations of $0 \%, 20 \%, 25 \%$ and $30 \%$.

The test results levels of vitamin $\mathrm{C}$ in the juice of papaya California is $0.0467 \%$. The test results of antioxidant activity using DPPH (1,1-diphenyl-2pikrihidrazil) papaya juice California has IC50 of $33.537 \mathrm{ppm}$ and the jelly formula 1 , 2, and 3 is equal to $75.296 \mathrm{ppm}, 73.901 \mathrm{ppm}$ and $70.698 \mathrm{ppm}$. Stability test conducted over 4 weeks of storage at room temperature. Results of testing the antioxidant activity in week 1 to 4 obtained $\mathrm{IC}_{50}$ values, respectively, are formula 1 of $81.171 \mathrm{ppm}, 89.573 \mathrm{ppm}, 97.178 \mathrm{ppm}$, and $102.126 \mathrm{ppm}$, formula 2 of $79.175 \mathrm{ppm}$,
\end{abstract}


$88.158 \mathrm{ppm}, 96.441 \mathrm{ppm}$, and $100.378 \mathrm{ppm}$, while in the third formula amounted to $77.255 \mathrm{ppm}, 85.482 \mathrm{ppm}, 93.680 \mathrm{ppm}$, and $100.267 \mathrm{ppm}$. Organoleptic jelly has the taste, color, aroma and resilience undergo significant changes.

Keywords : Jelly candy, California papaya (Carica papaya L.), Antioxidants

\section{PENDAHULUAN}

Indonesia sebagai negara berkembang mempunyai keterbatasan vdalam penanggulangan masalah kesehatan, dimana penyakit infeksi masih tinggi, tetapi privalensi penyakit degeneratif makin meningkat. Banyak penyakit yang disebabkan oleh radikal bebas, radikal bebas dapat mengoksidasi asam nukleat, protein, lipid sehingga menginisiasi terjadinya degeneratif dan kerusakan sel. Faktor lingkungan seperti polusi, intensitas UV yang berlebih, suhu, bahan kimia dan kekurangan gizi dapat mengakibatkan tubuh terpapar radikal bebas. Bila radikal bebas berlebihan akan menciptakan ketidakseimbangan antara molekul radikal bebas dan antioksidan endogen. Ketika jumlah radikal bebas melebihi kapasitas tubuh untuk menetralisirnya, maka terbentuk stres oksidatif yang menyebabkan kerusakan struktur sel, jaringan dan organ (Leong \& Shui, 2001).

Untuk meredam aktivitas radikal bebas diperlukan antioksidan. Antioksidan adalah molekul yang dapat mendonorkan elektronnya kepada molekul radikal bebas, sehingga menghentikan reaksi radikal bebas.Salah satu buah yang berpotensi mengandung antikoksidan adalah pepaya.

Pepaya (Carica papaya L.) merupakan jenis buah tropis yang buahnya manisdan dagingnya berwarna kuning kemerahan. Buah pepaya mengandung banyak vitamin terutama vitamin $A$, vitamin B9, vitamin $\mathrm{C}$ dan vitamin $\mathrm{E}$. Selain vitamin, pepaya juga mengandung mineral seperti fosfor, magnesium, zat besi, dan kalsium (Surtiningsih, 2005).

Menurut penelitian Marelli, et al.
(2008) buah pepaya memiliki kandungan vitamin $\mathrm{C}$ dan $\beta$-karoten yang bermanfaat sebagai antioksidan. Buah pepaya terkandung vitamin $C$ sebesar 70,2 $\mathrm{mg} / 100 \mathrm{~g}$ berat pepaya dan kandungan $\beta$ karoten sebesar 20,722 $\mu \mathrm{g} / 100 \mathrm{~g}$ berat pepaya.

Permen jelly merupakan permen yang terbuat dari campuran sari buahbuahan, bahan pembentuk gel atau dengan penambahan essens untuk menghasilkan berbagai macam rasa, dengan bentuk fisik jernih transparan serta mempunyai tekstur kenyal (Malik, 2010).

Melalui proses pembuatan sari buah pepaya menjadi permen jelly, diharapkan masih mempunyai khasiat sebagai antioksidan melalui analisis kadar vitamin C.

\section{METODE PENELITIAN \\ Bahan dan Alat}

Alat-alat yang digunakan dalam penelitian ini antara lain spektrofotometer UV-VIS (Optizen POP), juice extractor (Miyako), oven, neraca analitik, dan alatalat gelas.

Dan bahan-bahan yang digunakan pada penelitian ini adalah sari buah pepaya California (Carica Papaya L.) dari kelompok tani Mekarsari, karagenan, agar- agar, gula pasir, sirup glukosa, sodium propionate, asam sitrat, dan air. Pelarut dan pereaksi yang digunakan meliputi aquadest, metanol p.a, dan DPPH (1,1-difenil-2- pikrilhidrazil).

Pembuatan sari buah pepaya California yang digunakan sebanyak 850 gr. Pepaya dicuci bersih dengan menggunakan air mengalir kemudian ditiriskan dan ditrimming dengan tujuan 
untuk membuang bagian bonggol atau tangkai pada buah. Kemudian dilakukan pengupasan untuk memisahkan daging buah dari kulit dan bijinya. Pepaya dimasukkan ke dalam juice extractor, sari buah yang dihasilkan disimpan di wadah yang tertutup. Sari buah selanjutnya digunakan dalam pembuatan permen jelly.

\section{Uji Fitokimia}

Uji Flavonoid

$1 \mathrm{~mL}$ sari dimasukkan dalam tabung reaksi, dilarutkan dalam $3 \mathrm{~mL}$ etanol. Larutan diambil $1 \mathrm{~mL}$ dan ditambahkan 10 tetes $\mathrm{HCl}$ kemudian dipanaskan selama 10 menit. Hasil positif ditunjukkan oleh perubahan warna menjadi kuning, jingga, atau merah (Mustarichie, 2011).

\section{Uji Alkaloid}

$1 \mathrm{~mL}$ sari dimasukkan dalam tabung reaksi, dilarutkan dalam $5 \mathrm{~mL}$ kloroform. Larutan sari ditambahkan 5 mLHCl $2 \mathrm{M}$ dan $0,5 \mathrm{~g} \mathrm{NaCl}$. Campuran diaduk dan disaring. Filtrat yang diperoleh ditambah 3 tetes $\mathrm{HCl} 2 \mathrm{M}$ kemudian dipisahkan menjadi 4 bagian. Bagian pertama sebagai blanko, bagian kedua ditambahkan reagen Wagner, bagian ketiga ditambah dengan reagen Dragendroff, dan bagian keempat ditambah dengan reagen Mayer. Terbentuknya endapan menunjukkan adanya alkaloid (Mustarichie, 2011).

\section{Uji Tanin}

$1 \mathrm{~mL}$ sari dimasukkan dalam tabung reaksi, dilarutkan dalam $10 \mathrm{~mL}$ aquades panas kemudian didinginkan. Selanjutnya ditambahkan 5 tetes $\mathrm{NaCl}$ $10 \%$, dan saring. Filtrat yang diperoleh dibagi menjadi tiga bagian. Filtrat pertama sebagai blanko, filtrat kedua ditambahkan 3 tetes $\mathrm{FeCl} 3$, dan filtrat ketigaditambah 5 tetes gelatin. Hasil positif tanin ditunjukkan oleh adanya endapan putih (Mustarichie, 2011).

\section{Uji Saponin}

$1 \mathrm{~mL}$ sari dimasukkan dalam tabung reaksi, dilarutkan dalam 5 $\mathrm{mL}$ aquades panas kemudian dikocok selama 10 detik. Hasil positif ditunjukkan oleh terbentuknya buih atau busa yang stabil selama 10 menit (Mustarichie, 2011).

\section{Penetapan Kadar Vitamin C Sari Buah \\ Pepaya California \\ Pembuatan Larutan Induk Vitamin C}

Asam askorbat ditimbang sebanyak $25 \mathrm{mg}$ kemudian dimasukkan ke dalam labu ukur $250 \mathrm{~mL}$ dan dilarutkan dengan aquabides sampai tanda batas (Wardani, 2012).

\section{Penentuan Panjang Gelombang Maksimum Larutan Vitamin C}

Dipipet $1 \mathrm{~mL}$ larutan vitamin C 100 ppm dan dimasukkan kedalam labu ukur $50 \mathrm{~mL}$ (konsentrasi $2 \mathrm{ppm}$ ). Lalu ditambahkan aquabides sampai tanda batas dan homogenkan. Diukur serapan maksimum pada panjang gelombang $200-400 \quad \mathrm{~nm}$ dengan menggunakan blanko aquabides.

\section{Pembuatan Kurva Kalibrasi}

Larutan vitamin C 100 ppm dibuat deret masing - masing sebesar 4 ppm, 8 ppm, 12 ppm, 16 ppm pada labu $10 \mathrm{~mL}$. Kemudian ditambahkan aquabides hingga tanda batas lalu homogenkan, lalu diukur serapannya pada panjang gelombang maksimum yang diperoleh ( Wardani, 2012).

\section{Penentuan Kadar Sampel}

Sari buah pepaya ditimbang sebanyak $0.5 \mathrm{~mL}$, kemudian dimasukkan ke dalam labu ukur $100 \mathrm{~mL}$ lalu ditambahkan aquabides sampai tanda batas lalu dihomogenkan. Diukur serapannya pada panjang gelombang maksimum yang didapat. 
Uji reaksi antioksidan dengan 1,1difenil-2-pikrilhidrazil (DPPH)

Deret larutan uji, deret larutan kontrol positif dan blanko diukur serapannya pada panjang gelombang maksimum yang telah ditentukan dengan spektrofotometer. Nilai persentase hambatan terhadap DPPH dihitung menggunakan rumus berikut:

$$
\mathrm{C}_{0} \frac{\mathrm{Ab} \text { orban blanko-Ab orban ampel }}{\mathrm{Ab} \text { orban blanko }}
$$

Nilai $\mathrm{IC}_{50}$ (Inhibition Concentration 50) diperoleh dari perpotongan garis antara $50 \%$ daya hambat dengan sumbu konsentrasi menggunakan persamaan linear $(\mathrm{y}=\mathrm{bx}+\mathrm{a})$, dimana $\mathrm{y}=50$ dan $\mathrm{x}$ menunjukkan $\mathrm{IC}_{50}$.

\section{Proses Pembuatan Sediaan Permen Jelly}

Pertama karagenan dan agar-agar dilarutkan dalam air panas (60-700) kemudian ditambahkan gula pasir, sirup glukosa, dan sodium propionate ke dalam panci hingga campuran homogen. Kemudian dimasukkan sari buah pepaya California sambil terus-menerus diaduk sampai mulai mengental. Diikuti dengan penambahan asam sitrat. Adonan permen jelly yang telah masak langsung dimasukkan ke dalam cetakan ditutup dengan aluminium foil, kemudian dibiarkan sekitar 20 menit. Setelah dingin permen dikeluarkan dari cetakan, dipindahkan ke loyang kemudian di oven dengan suhu 500C selama \pm 8 jam.

\section{Uji Hedonik}

Uji hedonik dilakukan oleh panelis sebanyak 20 orang dewasa. Penilaian organoleptik yang dilakukan dalam uji hedonik ini meliputi warna, aroma, tekstur dan rasa. Skala yang digunakan terdiri dari lima tingkat, yaitu sangat suka (1), suka (2), netral (3), tidak suka (4), dan sangat tidak suka (5). Hasil analisa kesukaan diolah dengan menggunakan program statistik SPSS 17, dengan hasil a 0,0 . Kemudian diuji tati tik dengan metode Oneway ANOVA Duncan.

\section{Uji Analisis Mikroba kapang dan khamir \\ Sampel permen jelly yang telah dihancurkan ditimbang $1 \mathrm{~g}$,} kemudian dimasukkan dalam labu ukur $10 \mathrm{~mL}$ ditambah aquades steril hingga tanda batas sehingga diperoleh pengenceran 1:10, dan dikocok hingga larut. Kemudian diencerkan dengan pengenceran 1:100 dan 1:1000.

Dituang media Potato Dextrose Agar yang telah dicairkan bersuhu $45^{\circ} \mathrm{C}$ pada cawan petri steril , dibiarkan membeku pada cawan. Tiap pengenceran dipipet $1 \mathrm{~mL}$ ke dalam cawan petri yang steril (metode semai). Cawan petri digoyangkan dengan hati-hati, kemudian diinkubasi pada suhu $25^{\circ} \mathrm{C}$ selama 21 hari. Dihitung jumlah koloni kapang khamir dalam cawan petri pada masing-masing pengenceran. Jumlah mikroba kapang dan khamir maksimal $1 \times 10^{2}$ koloni/ml (Saifudin dkk, 2011).

\section{Uji Stabilitas}

Uji stabilitas dilakukan untuk permen jelly yang sudah terpilih dalam uji kesukaan. Uji stabilitas permen jelly ekstrak air buah ketapang dilakukan dalam kemasan plastik kedap air, dan dilakukan dengan mengamati stabilitas sediaan yang disimpan pada suhu kamar (250-300C) selama empat minggu, dan diuji tiap minggunya dimana pengamatannya terdiri dari beberapa parameter yaitu pemeriksaan organoleptik rasa, warna, aroma, tekstur, dan kadar antioksidan permen jelly.

\section{HASIL DAN PEMBAHASAN \\ Karakterisasi Sari Buah Pepaya California}


Sari buah adalah cairan yang diperoleh dari buah - buahan yang sehat dan segar serta digunakan sebagai minuman segar (Tri,dkk., 2000). Pepaya California yang digunakan sebanyak 850 g. Buah pepaya California di juice extractor diperoleh sari buah sebesar $440 \mathrm{~mL}$. Sari buah pepaya California memiliki karakteristik warna orange, rasa manis, dan aroma khas. Dari sari buah sebanyak $850 \mathrm{~g}$ bobot jenis yang dihasilkan sebesar $\quad 1,012 \mathrm{~g} / \mathrm{mL}$. Rendemen yang dihasilkan sebesar $52,3855 \%$. Kadar air buah pepaya sebesar $29,045 \%$ sedangkan sari buah pepaya didapatkan nilai sebesar 28,99 Uji fitokimia dilakukan untuk mengetahui senyawa yang terdapat pada sari buah. Hasilnya dapat dilihat pada tabel dibawah ini :

Tabel 1. Hasil Uji Fitokimia

\begin{tabular}{lll}
\hline Jenis Uji & Parameter & $\begin{array}{l}\text { Sari } \\
\text { Buah }\end{array}$ \\
\hline Flavonoid & $\begin{array}{l}\text { Merah } \\
\text { Jingga }\end{array}$ & + \\
Alkaloid : & & \\
a. Wagner & Endapan Coklat & - \\
b. Dragendrof & Endapan Merah & - \\
c. Mayer & Endapan Putih & - \\
Tanin & Endapan Putih & - \\
Saponin & Buih/Emulsi & - \\
\hline
\end{tabular}

\section{Hasil Penetapan Kadar Vitamin C}

Pengukuran kadar vitamin $\mathrm{C}$ dilakukan dengan metode spektrofotometri. Hal ini dilakukan untuk mengetahui kadar vitamin $\mathrm{C}$ yang terkandung dalam sari buah pepaya California dan permen jelly sari buah pepaya California. Dari hasil perhitungan persamaan regresi kurva diperoleh persamaan garis $\mathrm{y}=0.148 \mathrm{x}+0.055$ dengan koefisien korelasi (r) sebesar 0.998. Hasil penetapan kadar vitamin C dapat dilihat pada tabel 2 .

Tabel 2. Hasil Uji Fitokimia

\begin{tabular}{ll}
\hline Sampel & Kadar vitamin C \\
\hline Sari buah pepaya & $0,0467 \%$ \\
Permen Jelly & $0,0103 \%$ \\
\hline
\end{tabular}

Menurut Winarno (1997), vitamin C merupakan vitamin yang paling mudah rusak dibandingkan dengan jenis vitamin lainnya. Disamping sangat larut dalam air, vitamin $\mathrm{C}$ mudah teroksidasi dan proses tersebut dipercepat oleh panas, sinar, alkali, enzim, dan oksidator lainnya. Pada tabel terlihat bahwa kadar vitamin C mengalami perubahan setelah dibuat permen jelly. Hal ini bisa terjadi karena pada proses pembuatan permen jelly mengalami proses pemanasansehingga kadar vitamin $\mathrm{C}$ berkurang. Vitamin $\mathrm{C}$ yang terdapat pada permen jelly tidak menutup kemungkinan akan mengalami penurunan ketika telah diolah menjadi permen jelly sehingga rusaknya permen jelly karna proses pengolahan.

Semakin banyak suatu bahan pangan melalui proses pengolahan, maka akan berkurang nilai gizi atau vitamin yang terdapat dalam bahan tersebut. Vitamin $\mathrm{C}$ merupakan sumber antioksidan yang memberi manfaat bagi tubuh antara lain membantu menjaga kesehatan sel dan memperbaiki kekebalan tubuh (Kumalaningsih dan Suprayogi, 2006).

\section{Uji Kesukaan}

Berdasarkan hasil dianalisis dengan menggunakan program statistik SPSS 17 dengan metode Oneway ANOVA Duncan.

Tabel 3. Hasil Uji Hedonik

\begin{tabular}{|c|c|c|c|c|}
\hline $\begin{array}{l}\text { Permen } \\
\text { jelly }\end{array}$ & Rasa & Warna & Aroma & Kekenyalan \\
\hline Formula 0 & $2.25^{\mathrm{b}}$ & $2.15^{\mathrm{a}}$ & $3.40^{\mathrm{b}}$ & $2.05^{\mathrm{a}}$ \\
\hline $\begin{array}{l}\text { Formula } 1 \\
\text { Formula } 2\end{array}$ & $2.55^{\mathrm{b}}$ & $2.15^{\mathrm{a}}$ & $2.65^{\mathrm{a}}$ & $2.40^{\mathrm{b}}$ \\
\hline Formula 3 & $1.85^{\mathrm{a}}$ & $2.00^{\mathrm{a}}$ & $2.45^{\mathrm{a}}$ & $2.05^{\mathrm{a}}$ \\
\hline
\end{tabular}

Hasil uji hedonik dilihat dari Tabel berdasarkan hasil Output SPSS 17 dengan 
melihat nilai subsets menunjukkan bahwa rasa pada formula 2 dan 3 lebih disukai dibandingkan formula 1 ataupun formula 0 . Hasil analisis sidik ragam permen jelly formula 0 , dan formula 1 berbeda nyata dengan formula 2 , dan formula 3. Warna permen jelly formula 0 , formula 1 , formula 2 , formula 3 tidak berbeda nyata. Aroma permen jelly formula 1, formula 2, dan formula 3 lebih disukai dibanding formula 0 . Kekenyalan formula 2 dan 3 lebih disukai dibanding formula 1 tetapi tidak berbeda nyata terhadap formula 0 .

\section{Uji Mikroba}

Angka Kapang Khamir merupakan perhitungan dengan metode cawan yang dapat dilihat apabila ada satu sel mikroorganisme yang masih hidup ditumbuhkan pada medium yang sesuai, maka sel tersebut akan berkembang biak dan membentuk koloninya,dapat dilihat langsung dengan mata pada media yang digunakan setelah diinkubasi pada suhu $25-30^{\circ} \mathrm{C}$ selama 21 hari. Perhitungan dilakukan pada Konsentrasi cawan petri dengan jumlah koloni 10-150 koloni.

Berdasarkan analisis cemaran mikroba angka kapang dan khamir pada permen jelly didapatkan hasil < $1.0 \times 102$ koloni/gram. Hal tersebut menunjukkan bahwa nilai Angka Kapang Khamir dari permen jelly yang diujikan memenuhi syarat mutu permen jelly menurut SNI No. 01-3547-1994.

\section{Hasil Uji Stabilita Uji Organoleptis}

Hasil pengamatan organoleptis kelima formula permen jelly pada suhu kamar ( $250-300$ C). Setiap periode waktu penyimpanan dilakukan pengamatan organoleptis setiap 1 minggu sekali. Hasil pengamatan sediaan permen jelly minggu ke-0 secara umum menunjukkan bahwa permen mempunyai rasa, warna, aroma, dan kekenyalan yang homogen. Hal ini menunjukkan bahwa zat aktif dan basis permen jelly tercampur secara homogen.

Selama penyimpanan dari minggu ke 1 sampai minggu ke 4 permen jelly menunjukkan adanya perubahan pada rasa, warna, aroma, dan kekenyalan. Perubahan aroma dapat disebabkan oleh oksidasi dari udara luar. Perubahan warna yang cukup signifikan, pada formula 0 tidak terjadi perubahan sedangkan formula 1 , formula 2 , dan formula 3 terjadi perubahan yang signifikan yaitu rasa menjadi asam, perubahan warna orange yang semakin pekat, aroma menyengat dan kekenyalan semakin berkurang.

\section{Uji Aktivitas Antioksidan Permen Jelly}

Pengujian aktivitas antioksidan dilakukan dengan metode DPPH (2,2 difenil-1-pikrilhidrazil). Metode uji antioksidan dengan DPPH dipilih karena sederhana, mudah, cepat dan peka serta hanya memerlukan sedikit sampel. Absorban yang dihasilkan oleh reaksi reduksi ini diukur pada panjang gelombang $517 \mathrm{~nm}$.

Pengukuran aktivitas antioksidan setelah penyimpanan pada suhu kamar $(250-300$ C) selama 4 minggu bertujuan untuk mengetahui ketahanan aktivitas antioksidan selama penyimpanan.

Tabel 4. Aktivitas Antioksidan Permen Jelly

\begin{tabular}{|c|c|c|c|c|c|}
\hline \multirow[t]{2}{*}{ Formula permen Jelly } & \multicolumn{5}{|c|}{ Nilai $\mathrm{IC}_{50}(\mathrm{ppm})$ minggu ke- } \\
\hline & 0 & 1 & 2 & 3 & 4 \\
\hline 1 & 75,296 & 81,171 & 89,573 & 97,178 & 102,126 \\
\hline 2 & 73,901 & 79,175 & 88,158 & 96,441 & 100,378 \\
\hline 3 & 70,698 & 77,255 & 85,482 & 93,680 & 100,267 \\
\hline
\end{tabular}


Dari tabel diatas menunjukkan bahwa terjadi penurunan aktivitas antioksidan setelah sari diformulasikan pada sediaan permen jelly. Hal ini terjadi karena penurunan kadar vitamin $\mathrm{C}$ pada permen jelly sari buah pepaya disebabkan adanya pemanasan selama pengolahan dapat menyebabkan terjadinya degradasi vitamin $\mathrm{C}$ sehingga mampu mempercepat terjadinya oksidasi vitamin C. Menurut Winarno (1992), vitamin C mudah teroksidasi dan proses tersebut dipercepat oleh panas, sinar, alkali, enzim, oksidator serta oleh katalis tembaga dan besi. Pada proses pengolahan, kehilangan vitamin $\mathrm{C}$ akibat reaksi enzimatis jumlahnya sangat sedikit, sedangkan reaksi non-enzimatis menjadi penyebab utama hilangnya vitamin C (Wong, 1989). Vitamin $\mathrm{C}$ teroksidasi sehingga menghasilkan asam dehidroaskorbat (Padayatty, 2003). Reaksi reduksi dan oksidasi dapat dilihat pada Gambar 1.

Gambar 1. Reaksi reduksi dan oksidasi asam askorbat (Szent-Györgyi, 1937)

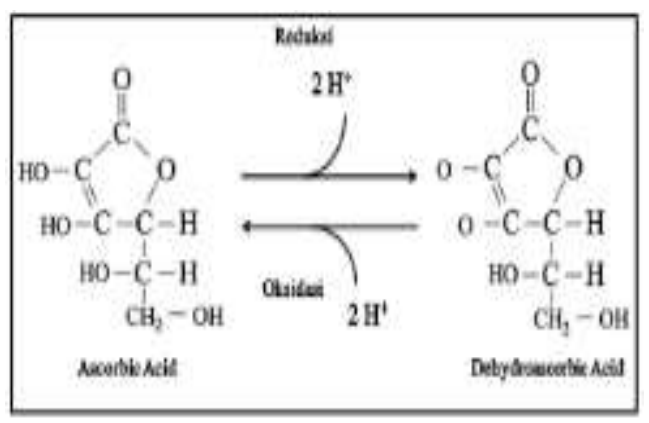

Terjadinya penurunan kadar antioksidan selama penyimpanan juga disebabkan oleh suhu penyimpanan. Penyimpanan pada temperatur lebih dari 270C dapat menyebabkan kehilangan vitamin $\mathrm{C}$ walaupun pada kondisi anaerob (Mapson, 1978 dalam Zentimer, 2007).

Vitamin C tergolong vitamin yang mudah larut dalam air (DeMan, 1997). Menurut Harris (1989), stabilitas asam askorbat akan meningkat dengan menurunnya nilai $\mathrm{pH}$. Vitamin $\mathrm{C}$ bersifat stabil dalam media asam, tetapi pada media netral dan basa sangat mudah terdegradasi oleh panas. Laju degradasi asam askorbat sebanding dengan konsentrasi oksigen terlarut dalam bahan pangan. Aktivitas antioksidan pada minggu ke 0 sampai ke 3 memiliki nilai $\mathrm{IC}_{50}$ diantara 50-100 ppm. Hal ini menunjukkan bahwa aktivitas aktivitas antioksidan permen jelly bersifat aktif. Pada minggu ke 4 memiliki nilai $\mathrm{IC}_{50}$ diantara 100-1000 ppm, hal ini menunjukkan bahwa nilai aktivitas antioksidan permen jelly bersifat aktif. Pada minggu ke 4 memiliki nilai IC50 diantara 100-1000 ppm, hal ini menunjukkan bahwa nilai aktivitas antioksidan permen jelly bersifat kurang aktif.

\section{KESIMPULAN DAN SARAN \\ Kesimpulan}

1. Berdasarkan hasil penelitian yang telah dilakukan dapat disimpulkan bahwa :

2. Kadar vitamin C sari buah pepaya sebesar $0,0467 \%$ dan permen jelly sari buah pepaya sebesar $0,0103 \%$.

3. Nilai IC $_{50}$ sari buah pepaya sebesar 33,537 ppm, permen jelly formula 1 sebesar 75,296 ppm, foemula 2 sebesar $73,901 \mathrm{ppm}$ dan formula 3 sebesar $70,698 \mathrm{ppm}$.

4. Permen jelly sari buah memiliki kestabilan rasa, warna, aroma, dan kekenyalan selama 4 minggu.

\section{Saran}

Saran yang perlu dilakukan untuk penelitian berikutnya adalah :

1. Perlu dilakukan pengujian $\beta$ karoten dan flavonoid terhadap sari buah dan permen jelly sari buah pepaya. 
2. Perlu dilakukan preformulasi agar didapatkan permen jelly yang lebih kenyal.

\section{DAFTAR PUSTAKA}

Albert Szent-Gyorgyi' Bioghrapy: The Nobel Prize in Physiology or Medicine1937, dalam: Fernandes, D. 2006. Vitamin C. Stanford: Standford University. 211-214.

Deman, John. M. $1997 . \quad$ Kimia Makanan.Terjemahan Kosasih Padwawinata. Penerbit ITB Bandung.

Harris, R.S. dan E. Karmas. 1989. Evaluasi Gizi Pada Pengolahan Bahan Pangan. Penerbit ITB. Bandung.

Kumalaningsih, S., Suprayogi, dan B. Yuda.2005. Tekno Pangan. Membuat Makanan Siap Saji. Trubus Agrisarana 2005: Surabaya.

Leong, L. P. \& Shui, G. 2002. An Investigation of Antioxidant Capacity of Fruits in SingaporeMarkets. Food chemistry. 76:69-75. Surtiningsih. 2005. Cantik dengan Bahan Alami. Jakarta: PT. Elex Media Komputido.

Malik, Iwan. 2010. Permen Jelly Yup.http://iwanmalik.wordpress.co $\mathrm{m} / 2010 /$ permen jelly/ [10 Juni 2015] Mapson, L.W., 1978. Vitamine in Fruit: Biochemistry of
Fruit and Their Product, Food Science and Technology. Academic Press, London.

Marelli de souza,L., ferreira,

K.S.,Chaves, J.B.P., dan Teixeira, S.L. (2008). L- ascorbic Acid, BetaCarotenen and Lycopen Content in Papaya Fruit (Carica papaya L.) Whith or Whitout Physiological Skin Freckle. Journal Sci.agri. (Peracicaba, Braz).65, (3).

Mustarichie, R., Misfiroh, I., \& Levita, J.2011. Penelitian Kimia Tanaman Obat. Bandung: Widya Padjajaran.

Saifudin, A., 2011. Standarisasi Bahan Obat Alam. Yogyakarta: Graha Ilmu.

Tri Margono, Detty Suryati, Sri Hartinah.2000. Buku Panduan Teknologi Pangan. Pusat Informasi Wanita Dalam Pembangunan, PDII, LIPI. Jakarta. Hal 1-4.

Wardani, L.A. 2012. Validasi Metode Analisis dan Penentuan Kadar Vitamin C Pada Minuman buah Kemasan Dengan Spektrofotometri $U V$-Visibel. FMIPA. Depok.

Winarno, F.G., 1992. Pangan, Enzim dan Konsumen. Gramedia Pustaka Utama, Jakarta.

Winarno, F.G., 1997. Kimia Pangan dan Gizi. Jakarta: PT. Gramedia.Wong, Dominic, W.S., 1889. Mechamism And Theory In Food Chemistry. Van Nostrand Reinhold. New york. 